\title{
NEW EVIDENCE ON THE RELATIONSHIPS BETWEEN HYPNOPHILA BOURGUIGNAT, 1859 AND GOMPHROA WESTERLUND, 1902 (GASTROPODA: EUPULMONATA: AZECIDAE)
}

\author{
GIUSEPPE MANGANELLI ${ }^{1 *}$, JOANNA PIEŃKOWSKA ${ }^{2}$, EWA KOSICKA² ${ }^{2}$ DEbORA BARBATO ${ }^{1}$, \\ ANDREA BENOCCI ${ }^{3}$, ANDRZEJ LESICKI ${ }^{2}$, FOLCO GIUSTI ${ }^{1}$
}

\begin{abstract}
'Dipartimento di Scienze Fisiche, della Terra e dell'Ambiente, Università di Siena, Via Mattioli 4, 53100 Siena, Italy (e-mails: manganelli@unisi.it; debora.barbato87@gmail.com; fg@urfz.org); (1) GM https://orcid.org/0000-0002-8453-280X, (1) DB https://orcid.org/0000-0003-1105-1711, (1) FG https://orcid.org/0000-0001-8722-4653

${ }^{2}$ Department of Cell Biology, Institute of Experimental Biology, Faculty of Biology,

Adam Mickiewicz University, Poznań, Uniwersytetu Poznańskiego 6, 61-614 Poznań, Poland (e-mails: pienkowj@amu.edu.pl; ewatom@amu.edu.pl; alesicki@amu.edu.pl); (1) JRP https://orcid.org/0000-0003-0372-121X, (1) EK https://orcid.org/0000-0001-7969-4153, (1) AL https://orcid.org/0000-0002-1924-1934

${ }^{3}$ Museo di Storia Naturale dell'Accademia dei Fisiocritici, Piazzetta S. Gigli 2, 53100 Siena, Italy (e-mail: andrea.benocci.76@gmail.com); () https://orcid.org/0000-0003-3145-215X

*corresponding author
\end{abstract}

ABSTRACT: Analysis of nucleotide sequences of mitochondrial COI and nuclear $5.8 \mathrm{~S}+\mathrm{ITS} 2+28 \mathrm{~S}$ gene fragments was performed on newly obtained specimens of Hypnophila pupaeformis (Cantraine). The results partially agree with previous morphological (shell and genitalia) analysis. They support separateness of H. pupaeformis from all species assigned to Gomphroa, Cryptazeca, Hypnocarnica and Azeca. They also show close relationships of $\mathrm{H}$. pupaeformis with the Gomphroa group. Indeed Hypnophila and Gomphroa form a clade consisting of four subclades: Hypnophila and three lineages named provisionally Gomphroa A, Gomphroa B and Gomphroa C. However, more research is needed to determine their relationships and to establish whether Hypnophila and Gomphroa are two genera or two (or even four) subgenera of one genus.

KEY WORDS: Azecidae; genera; systematics; molecular features; COI; ITS2; nucleotide sequences

\section{INTRODUCTION}

Azecids, a small group of litter and topsoil snails, can be found in Europe from the British Isles southward to the Iberian Peninsula and eastward to the western part of the Balkan Peninsula, as well as in North Africa from Morocco to Algeria (HOLYOAK \& HOLYOAK 2012, WELTER-SCHULTES 2012, ŠTAMOL et al. 2018, MANGANELLI et al. 2019). After several years of discussion (MANGANELLI et al. 2019), they are currently accepted as a distinct family of orthurethran pulmonates: Azecidae Watson, 1920 (e.g. HOLYOAK \& HOLYOAK 2012, BANK \& NEUBERT 2017,
BOUCHET et al. 2017, CIANFANELli et al. 2018a, b, ŠTAMOL et al. 2018).

However discussion on division of the family into genera continues. In addition to the three long-recognised genera, i.e. Azeca Fleming, 1828, Hypnophila Bourguignat, 1859, and Cryptazeca Folin et Bérillon, 1877, two new genera were recently established: Gomeziella Cianfanelli, Bodon, Giusti et Manganelli, 2018(a) and Hypnocarnica Cianfanelli et Bodon in Cianfanelli et al., 2018(b). Last year MANGANELLI et al. (2019) stated that the genus 
Hypnophila should be divided in two: Gomphroa Westerlund, 1902 and Hypnophila s.str. The former occurs in the western Mediterranean area and includes nine western Hypnophila species, namely G. bisacchii (Giusti, 1970), G. boissii (Dupuy, 1851), G. cylindracea (Calcara, 1840), G. dohrni (Paulucci, 1882), G. emiliana (Bourguignat, 1859), G. etrusca (Paulucci, 1886), G. incerta (Bourguignat, 1859), G. malagana (Gittenberger et Menkhorst in Gittenberger, 1983) and G. remyi (Boettger, 1949), plus the Dalmatian G. zirjensis (Štamol, Manganelli, Barbato et Giusti, 2018). The latter - with the other four Hypnophila species: H. pupaeformis (Cantraine, 1835), H. polita

\section{MATERIAL AND METHODS}

\section{TAXONOMIC SAMPLE}

Four specimens of $H$. pupaeformis were collected in the vicinity of Špilja Šipun (Šipun Cave, Rat peninsula, Cavtat, n. Dubrovnik, Croatia, $42^{\circ} 35.08^{\prime} \mathrm{N}$, $18^{\circ} 13.03 ' \mathrm{E}$; OZIMEC 2012) by B. JALŽIĆ on 15.5.2018 (material in Folco Giusti collection, FGC 48643). They were compared with other azecid species analysed in a previous paper (MANGANELLI et al. 2019), using Cochlicopa lubrica (Müller, 1774), traditionally regarded as allied with the azecids, as outgroup.

\section{MOLECULAR ANALYSIS}

Nucleotide sequences of the following gene fragments were analysed: mitochondrial 5 '-end of cytochrome c oxidase subunit I (COI), as well as nuclear 3'-end of 5.8S ribosomal DNA (5.8S), complete internal transcribed spacer 2 in ribosomal DNA (ITS2), 5'-end of 28S ribosomal DNA (28S) and histone $\mathrm{H} 3(\mathrm{H} 3)$.

DNA e $x \mathrm{traction}, \quad$ a m plification a n d s e que n c in g

Small foot tissue fragments of alcohol preserved snails were used for total DNA extraction with Tissue Genomic DNA extraction Mini Kits (Genoplast) according to the manufacturer's instructions. The purified total DNA was used as template for amplification by polymerase chain reaction (PCR) of partial sequences, using the following primers: for COI - two Folmer's "universal" primers LCO1490 (5'-GGTCAACAAATCATAAAGATATTGG-3') and HC02198 (5'-TAAACTTCAGGGTGACCAAAAAATCA-3') (FOLMER et al. 1994); for $5.8 S+\mathrm{ITS} 2+28 \mathrm{~S}$ - the pair of primers LSU-1 (5'-CTAGCTGCGAGAATTAATGTGA-3') and LSU3 (5'-ACTTTCCCTCACGGTACTTG-3') (WADE \& MORDAN 2000); for $\mathrm{H} 3$ - the pair of primers H3F (5'-ATGGCTCGTACCAAGCAGACVGC-3') and H3R
(Porro, 1838), H. cyclothyra (Boettger, 1885) and $H$. zacynthia (Roth, 1855) - is known from the western Balkan Peninsula, islands included.

Division of Hypnophila s.l. into two genera is well supported by morphological analysis (shell features and genital anatomy). Molecular studies (analysis of nucleotide sequences of selected fragments of mitochondrial and nuclear genes) have confirmed that the species included in the genus Gomphroa form a closely related group, but molecular comparison with species of true Hypnophila has not hitherto been undertaken. Molecular analysis of newly obtained material of Hypnophila pupaeformis is presented in this paper.

\section{(5'-ATATCCTTRGGCATRATRGTGAC-3') (COLGAN} et al. 1998).

All polymerase chain reactions were performed in a volume of $10 \mu \mathrm{l}$. The amplified COI fragments, consisting of 710 base pairs (bp), were obtained under the following thermal profile: $5 \mathrm{~min}$ at $95^{\circ} \mathrm{C}$ followed by 35 cycles of $30 \mathrm{~s}$ at $95^{\circ} \mathrm{C}, 1 \mathrm{~min}$ at $50^{\circ} \mathrm{C}, 1 \mathrm{~min}$ at $72{ }^{\circ} \mathrm{C}$, and finally $5 \mathrm{~min}$ at $72{ }^{\circ} \mathrm{C}$ using the Type-it Microsatellite PCR Kit (Qiagen). Amplification products of ITS2 with 5.8S and 28S flanking fragments of 944-945 bp (including 52-53, 573 and 319 bp for $5.8 \mathrm{~S}$, ITS2 and 28S, respectively) were obtained using the same cycling parameters. Two rounds of amplifications were performed: the first with the purified total DNA as template and the second with $1 \mu \mathrm{l}$ of the $10 \times$ diluted product from the first round as template. The amplified $\mathrm{H} 3$ sequences consisted of 429 bp. PCR reactions $(10 \mu \mathrm{l})$ were performed according to the procedure described by COLGAN et al. (1998).

The PCR products were verified by agarose gel electrophoresis ( $1 \%$ agarose). Prior to sequencing, samples were purified with thermosensitive Exonuclease I and FastAP Alkaline Phosphatase (Fermentas, Thermo Scientific). Finally, the amplified products were sequenced in both directions with BigDye Terminator v3.1 on an ABI Prism 3130XL Analyzer (Applied Biosystems, Foster City, CA, USA) according to the manufacturer's protocols.

Sequences were edited by eye using the programme BIOEDIT, version 7.0.6 (HALL 1999). The alignments were performed using the CLUSTAL W programme (THOMPSON et al. 1994) implemented in MEGA 7 (KumAr et al. 2016). The COI and H3 sequences were aligned according to the translated amino acid sequences. Gaps and ambiguous positions were removed from COI alignments prior to phylogenetic analysis. The ends of all sequences were trimmed. The lengths of the COI and $\mathrm{H} 3$ sequences after cutting were 476 and 252 bp, respectively. Sequences consisting of the 3 '-end of 5.8S, ITS2 and 5'-end of 
$28 \mathrm{~S}$ were aligned with sequences from GenBank. The alignment of all sequences was 1,052 positions (base pairs +indels) in length. In the analysis of ITS2 and 28S, treated separately, the alignments were 784 and 319 positions in length, respectively. The sequences were collapsed to haplotypes (COI) and to common sequences (5.8S+ITS2+28S) using the programme ALTER (Alignment Transformation EnviRonment) (GLEZ-PEÑA et al. 2010). Finally COI haplotypes and $5.8 \mathrm{~S}+\mathrm{ITS} 2+28 \mathrm{~S}$ common sequences were joined into concatenated sequences COI $+(5.8 \mathrm{~S}+\mathrm{ITS} 2+28 \mathrm{~S})$ and the resulting alignment was 1,318 positions in length $(476 \mathrm{COI}+8425.8 \mathrm{~S}+\mathrm{ITS} 2+28 \mathrm{~S})$.

\section{Phylogenetic inference}

The sequences deposited in GenBank are shown in Table 1.

For each alignment file, best nucleotide substitution models were specified according to the
Bayesian Information Criterion (BIC): for COI, concatenated 5.8S+ITS2+28S and concatenated $\mathrm{COI}+(5.8 \mathrm{~S}+\mathrm{ITS} 2+28 \mathrm{~S})$ sequences, $\mathrm{T} 92+\mathrm{G}+\mathrm{I}$ (TAMURA 1992); for 28S sequences, JC+G (JUKES \& CANTOR 1969); for ITS2, K2+G (KIMURA 1980). Maximum Likelihood (ML) analyses were performed with MEGA 7 (KUMAR et al. 2016). For the set of concatenated $\mathrm{COI}+(5.8 \mathrm{~S}+\mathrm{ITS} 2+28 \mathrm{~S})$ sequences, Bayesian Inference (BI) was also conducted with the programme MrBayes 3.1.2 (RONQUIST \& HUELSENBECK 2003). The same nucleotide substitution model was used as in ML analysis. Four Monte Carlo Markov chains were run for 1 million generations, sampling every 100 generations (the first $25 \%$ of trees were discarded as 'burn-in'). A 50\% majority rule consensus tree was obtained as a result. Cochlicopa lubrica was added as an outgroup species in each analysis.

\section{RESULTS}

Two new COI, four 5.8S+ITS2 $+28 \mathrm{~S}$ and four H3 sequences were obtained from the specimens of $H$. pupaeformis from Croatia and deposited in GenBank (Table 1). Partial sequences of mitochondrial COI

and nuclear $5.8 \mathrm{~S}+\mathrm{ITS} 2+28 \mathrm{~S}$ gene fragments were compared with sequences of these genes deposited in GenBank by other authors (see: Table 1) (H3 sequences were not used in phylogenetic analysis

Table 1. Sequences deposited in GenBank used in phylogenetic analysis

\begin{tabular}{|c|c|c|c|c|c|}
\hline \multicolumn{2}{|c|}{ Species } & \multirow{2}{*}{$\mathrm{COI}$} & \multirow{2}{*}{$5.8 \mathrm{~S}+\mathrm{ITS} 2+28 \mathrm{~S}$} & \multirow{2}{*}{$\mathrm{H} 3$} & \multirow{2}{*}{ References } \\
\hline original taxonomy & revised taxonomy & & & & \\
\hline \multirow[t]{4}{*}{ Azeca goodalli } & Azeca goodalli & MG209139 & MG209165 & & CIANFANELLI et al. $2018 \mathrm{~b}$ \\
\hline & & & MG209166 & & \\
\hline & & & FJ791121 & & MADEIRA et al. 2010 \\
\hline & & & AY546470 & & ARMBRUSTER et al. 2005 \\
\hline Hypnophila sp. A & Gomphroa sp. (1) & MG209145 & MG209173 & & CIANFANELLI et al. 2018b \\
\hline Hypnophila sp. B & Gomphroa sp. (2) & MG209152 & MG209179 & & CIANFANELLI et al. 2018b \\
\hline Hypnophila etrusca & Gomphroa etrusca & MG209147 & MG209175 & & CIANFANELLI et al. $2018 \mathrm{~b}$ \\
\hline Hypnophila bisacchii & Gomphroa bisacchii & MG209143 & MG209171 & & CIANFANELLI et al. 2018b \\
\hline Hypnophila boissii & Gomphroa boissii & MG209144 & MG209172 & & CIANFANELLI et al. 2018b \\
\hline \multirow[t]{2}{*}{ Hypnophila malagana } & Gomphroa malagana & MG209149 & MG209176 & & CIANFANELLI et al. 2018b \\
\hline & & & FJ791123 & & MADEIRA et al. 2010 \\
\hline Hypnophila dohrni & Gomphroa dorhni & MG209146 & MG209174 & & CIANFANELLI et al. $2018 \mathrm{~b}$ \\
\hline Hypnophila remyi & Gomphroa remyi & MG209150 & MG209177 & & CIANFANELLI et al. $2018 \mathrm{~b}$ \\
\hline Hypnocarnica micaelae & Hypnocarnica micaelae & MG209151 & MG209178 & & CIANFANELLI et al. 2018b \\
\hline \multirow{2}{*}{ Cryptazeca monodonta } & Cryptazeca monodonta & MG209140 & MG209167 & & CIANFANELLI et al. 2018b \\
\hline & & & FJ791122 & & MADEIRA et al. 2010 \\
\hline \multirow[t]{3}{*}{ Cryptazeca spelaea } & Cryptazeca spelaea & MG209141 & MG209168 & & CIANFANELLI et al. 2018b \\
\hline & & & MG209169 & & \\
\hline & & MG209142 & MG209170 & & \\
\hline \multirow[t]{4}{*}{ Hypnophila pupaeformis } & Hypnophila pupaeformis & & MT261889 & MT263751 & This paper \\
\hline & & MT260977 & MT261890 & MT263752 & This paper \\
\hline & & MT260978 & MT261891 & MT263753 & This paper \\
\hline & & & MT261892 & MT263754 & This paper \\
\hline \multirow[t]{2}{*}{ Cochlicopa lubrica } & Cochlicopa lubrica & MF545160 & & & DEWAARD 2017 \\
\hline & & & AY014019 & & WADE et al. 2001 \\
\hline
\end{tabular}




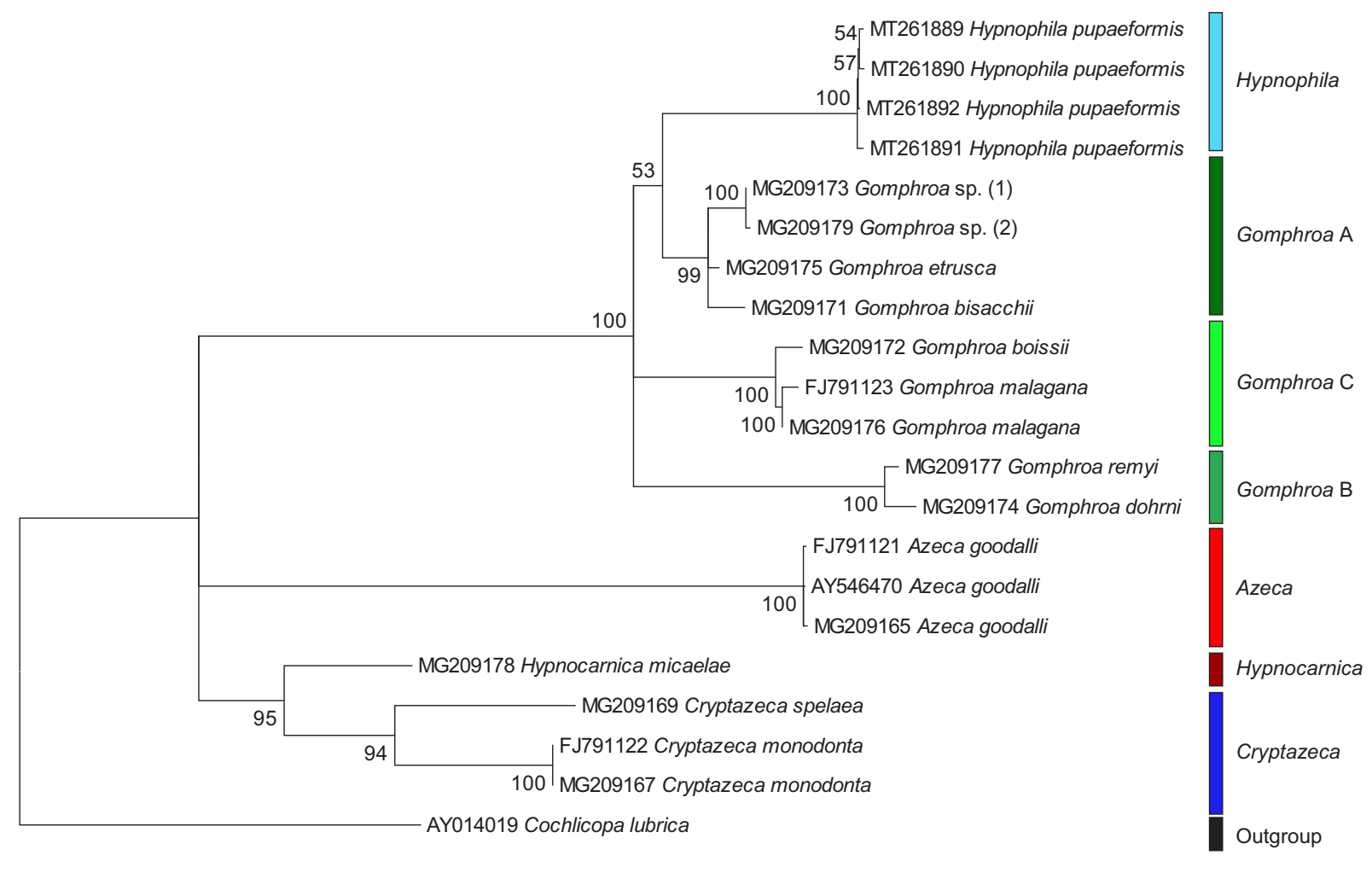

0.1

Fig. 1. Maximum Likelihood (ML) tree of concatenated 5.8S+ITS2+28S sequences of Azecidae, based on sequences obtained from GenBank (see Table 1). Numbers next to branches indicate bootstrap support above $50 \%$ calculated for 1,000 replicates (FELSENSTEIN 1985). The tree was rooted with Cochlicopa lubrica sequence AY014019 deposited in GenBank by WADE et al. (2001)

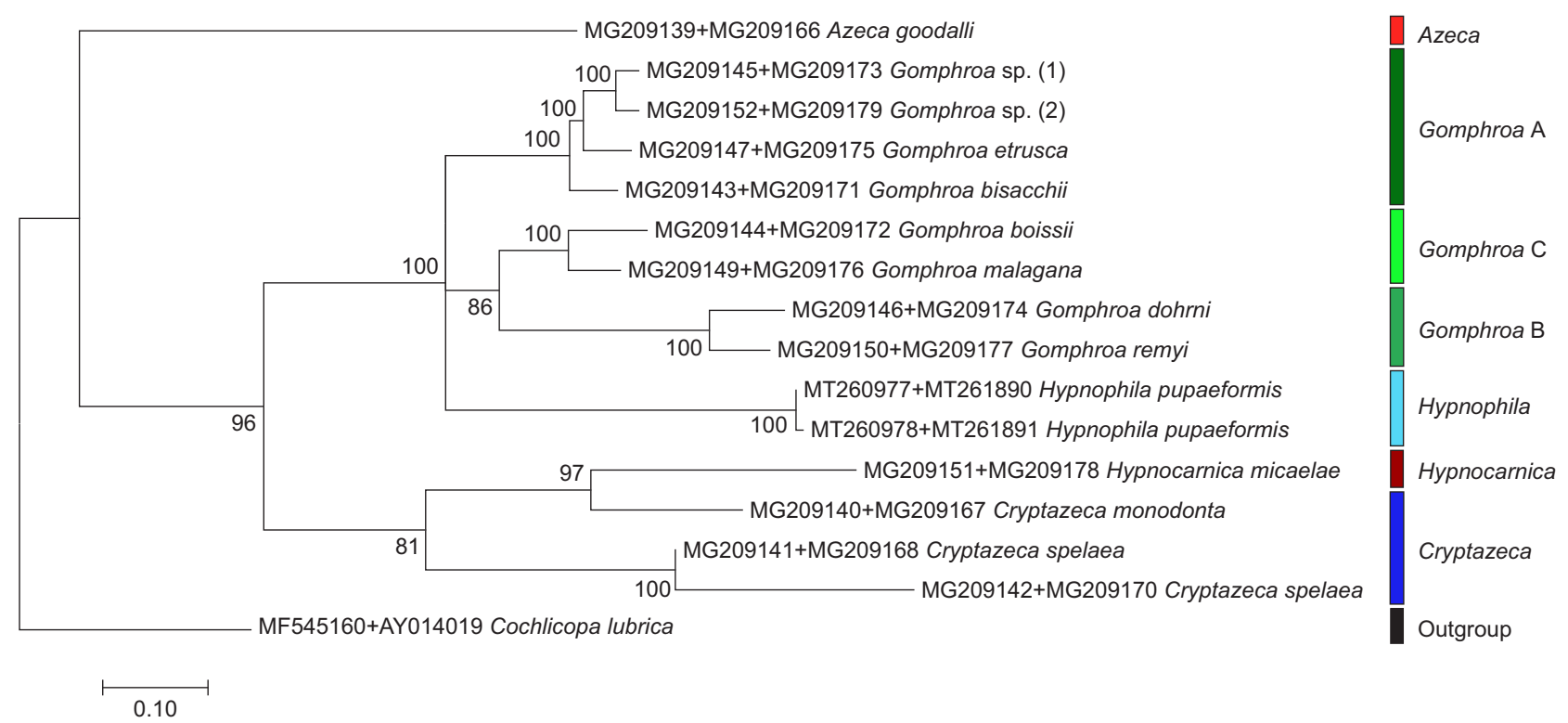

Fig. 2. Maximum Likelihood (ML) tree of concatenated COI+ $(5.8 \mathrm{~S}+\mathrm{ITS} 2+28 \mathrm{~S})$ sequences of Azecidae, based on sequences obtained from GenBank (see Table 1). Numbers next to branches indicate bootstrap support above $50 \%$ calculated for 1,000 replicates (FELSENSTEIN 1985). The tree was rooted with Cochlicopa lubrica concatenated sequence of MF545160 and AY014019, deposited in GenBank by DEWAARD (2017) and WADE et al. (2001), respectively 
because no reference sequences could be found in GenBank resources). ML trees with phylogenetic analysis of single locus datasets of COI, ITS2 and 28S (not shown) and the multilocus dataset of concatenated 5.8S+ITS2+28S sequences (Fig. 1) showed that $H$. pupaeformis sequences were grouped on distinct branches. The same result was obtained for concatenated $\mathrm{COI}+(5.8 \mathrm{~S}+\mathrm{ITS} 2+28 \mathrm{~S})$ sequences in ML (Fig. 2) and BI (Fig. 3) analysis.

K2P distances between COI sequences were smaller in particular genera (Table 2), especially those represented by single species (Hypnophila $0.2 \%$ ), suggesting small intraspecies variation. They were larger in genera represented by more species (Cryptazeca 10.9-16.1\%, Gomphroa 9.0-21.9\%). However, even then they were smaller than the K2P distances between particular genera (K2P $>20.0 \%$ ), except between two pairs, i.e. Cryptazeca and Gomphroa (16.925.2\%) and Gomphroa and Hypnophila (15.9-20.5\%), due to larger variation within Gomphroa.
Table 2. K2P genetic distances between the analysed COI sequences (of $476 \mathrm{bp}$ in length)

\begin{tabular}{lc}
\hline & K2P distance (\%) \\
\hline Within Azeca & $\mathrm{n} / \mathrm{c}^{*}$ \\
Within Cryptazeca & $10.9-16.1$ \\
Within Gomphroa & $9.0-21.9$ \\
Within Hypnocarnica & $\mathrm{n} / \mathrm{c}^{*}$ \\
Within Hypnophila & 0.2 \\
Azeca vs. Cryptazeca & $31.1-34.7$ \\
Azeca vs. Gomphroa & $30.1-34.7$ \\
Azeca vs. Hypnocarnica & 36.6 \\
Azeca vs. Hypnophila & $28.1-28.4$ \\
Cryptazeca vs. Gomphroa & $16.9-25.2$ \\
Cryptazeca vs. Hypnocarnica & $21.1-25.4$ \\
Cryptazeca vs. Hypnophila & $20.2-21.8$ \\
Gomphroa vs. Hypnocarnica & $21.0-24.8$ \\
Gomphroa vs. Hypnophila & $15.9-20.5$ \\
Hypnocarnica vs. Hypnophila & $21.9-22.2$ \\
\hline
\end{tabular}

$*-\mathrm{n} / \mathrm{c}$ (not counted) as only single specimens of the genus were analysed.

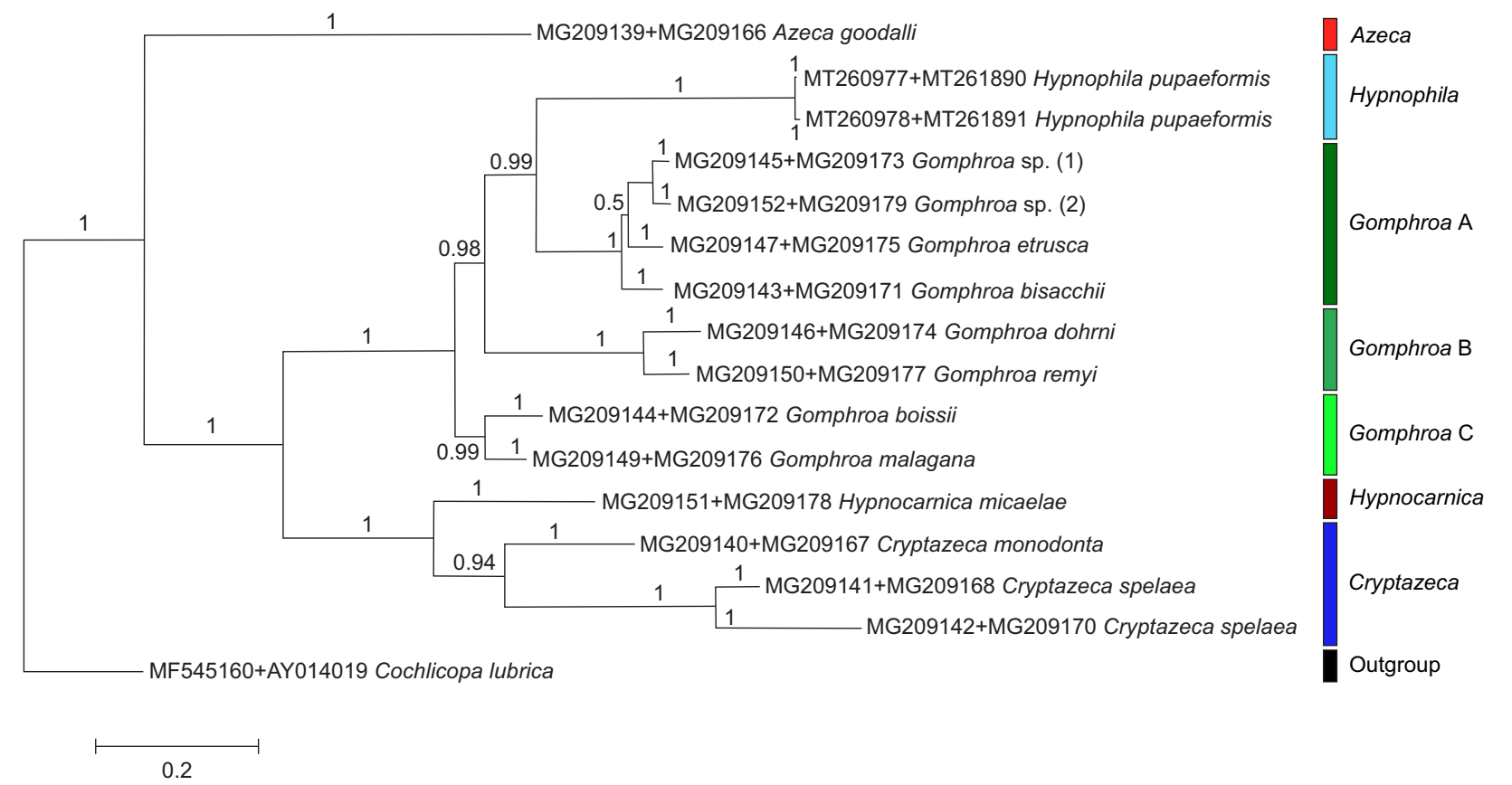

Fig. 3. Bayesian Inference (BI) tree of concatenated COI+ $(5.8 S+I T S 2+28 S)$ sequences of Azecidae, based on sequences obtained from GenBank (see Table 1). Posterior probability values are indicated next to the branches. The tree was rooted with Cochlicopa lubrica concatenated sequence of MF545160 and AY014019, deposited in GenBank by DEWAARD (2017) and WADE et al. (2001), respectively

\section{DISCUSSION}

Phylogeny based on morphological characters, which was presented in a previous paper (MANGANELLI et al. 2019), showed that true Hypnophila species belong to a monophyletic group supported by two synapomorphies: the elongate ovoid-cylindrical shell and the cup-like initial por- tion of one of the two penial plicae bordering the vas deferens opening into the penis. This clade constituted the sister group of Azeca based on loss of the rows of pits on the protoconch. In turn, Azeca plus Hypnophila was the sister group of the lineage including Gomphroa species except G. boissii, based on 
the transversely elongated tubercle on the outermost parietum. This analysis of morphological characters was also confirmed by molecular analysis of the sequences then available (MANGANELLI et al. 2019).

MANGANELLI et al. (2019) suggested that 15 species previously included in Hypnophila (GIUSTI \& MANGANELlI 1984, WeLTER-SCHULTES 2012, ŠTAMOL et al. 2018) should be divided into two separate genera: Gomphroa and Hypnophila s.str. The former included nine species of Gomphroa, all but one of which occur in the western Mediterranean (the one exception is the Dalmatian G. zirjensis). The latter comprised the remaining four species of Hypnophila with distribution in the western Balkan Peninsula, including the western Balkan islands. Two species of Gomphroa occurring in north western Africa (G. maroccana (Mousson, 1873), G. psathyrolena (Bourguignat, 1859)) were not included in the analysis because they were only known from the original description and very few other contributions (ŠTAMOL et al. 2018, MANGANELLI et al. 2019).

The new molecular data strongly support the separateness of $H$. pupaeformis from all other azecid species as well as its close relationships with the Gomphroa group. Indeed, each analysis of gene sequences obtained from $H$. pupaeformis, i.e. those concerning separate analysis of each gene (mitochondrial COI or nuclear ITS2 and 28S) as well as those of concantenated sequences (5.8S+ITS2+28S, Fig. 1; $\mathrm{COI}+(5.8 \mathrm{~S}+\mathrm{ITS} 2+28 \mathrm{~S})$, Figs $2-3)$, showed a clearly distinct branch for $H$. pupaeformis, separate from those of species belonging to Gomphroa, Hypnocarnica, Cryptazeca and Azeca, on the phylogenetic trees. The $\mathrm{K} 2 \mathrm{P}$ distances of COI sequences found in this paper are similar to those published by MANGANELLI et al. (2019), which are now supplemented by analysis of COI from $H$. pupaeformis (not previously available). Some differences in the results (MANGANELLI et al. 2019: table 4 and this paper: Table 2) are derived from the need to trim the COI sequences to $476 \mathrm{bp}$. However, the branch for H. pupaeformis sequences forms a subclade within the group of species assigned to Gomphroa in each tree, indicating that Gomphroa is paraphyletic. Gomphroa sensu Manganelli et al. (2019) may be divided into three subgroups named provisionally Gomphroa A, Gomphroa B and Gomphroa C (Figs 1-3). The K2P distances within and between these groups are similar, and similar K2P distances also distinguish all Gomphroa groups and $H$. pupaeformis (Table 3). Gomphroa A includes some species from Provence, Tuscany, the Tuscan Archipelago, Sardinia and the Pontine Archipelago; Gomphroa B includes the Sardinian G. dohrni and the Corsican G. remyi; Gomphroa C includes two Iberian species (CIANFANELli et al. 2018b, ŠTAMOL et al. 2018). The relationships between these groups and Hypnophila are still unclear: Hypnophila may be the sister group
Table 3. K2P genetic distances between the analysed COI sequences within three Gomphroa subgroups and Hypnophila pupaeformis

\begin{tabular}{lc}
\hline & K2P distance (\%) \\
\hline Within Hypnophila & 0.2 \\
Within Gomphroa A & $9.0-14.7$ \\
Within Gomphroa B & 19.5 \\
Within Gomphroa C & $16.6-21.9$ \\
Hypnophila vs. Gomphroa A & $15.9-20.2$ \\
Hypnophila vs. Gomphroa B & $18.9-20.5$ \\
Hypnophila vs. Gomphroa C & $16.7-20.5$ \\
Gomphroa A vs. Gomphroa B & $17.5-21.7$ \\
Gomphroa A vs. Gomphroa C & $18.0-23.2$ \\
Gomphroa B vs. Gomphroa C & $18.3-20.5$ \\
\hline
\end{tabular}

of Gomphroa A; in turn, this clade has unresolved relationships with Gomphroa B and Gomphroa C (Fig. 1); Hypnophila may have unresolved relationships with Gomphroa A and the clade consisting of Gomphroa B plus Gomphroa C (Fig. 2); Hypnophila may be a sister group of Gomphroa A; in turn, this clade is a sister group of Gomphroa B and in turn the last clade is a sister group of Gomphroa C (Fig. 3). The division of Gomphroa into three separate subgroups is not supported by any morphological feature. Although the Sardo-Corsican Gomphroa B may be distinct due to a proportionally smaller penis (MANGANELLI et al. 2019), the Iberian Gomphroa $C$ includes species with a "normal" penis (G. malagana) as well as species with a micropenis (G. boissii). On the contrary, the distinction between Gomphroa and Hypnophila is also supported by some shell and genital features (MANGANELLI et al. 2019). We have always stressed (PIEŃKOWSKA et al. 2018, 2019) that molecular features alone are insufficient to make taxonomic conclusions but that they must be supported by morphological and anatomical features. Thus any taxonomic conclusion concerning the relationship between the genera Gomphroa and Hypnophila seems to be premature. At the moment we can only confirm the separateness of $H$. pupaeformis from all species assigned to Gomphroa, as well as to Cryptazeca, Hypnocarnica and Azeca. More research is needed to determine whether Hypnophila and Gomphroa represent two genera, or two (or even four) subgenera of one genus. Further research should include at least some of the other Greek Hypnophila species ( $H$. polita, H. cyclothyra and H. zacynthia) and some other Gomphroa species such as the Dalmatian G. zirjensis and one or more Sicilian species. Nor is any division of Gomphroa into further subgenera possible at the present time. In our analysis, we again used sequences deposited in GenBank by CIANFANELLI et al. (2018b) for single specimens representing particular species assigned to Gomphroa (MANGANELLI et al. 2019). Consequently, more specimens of at least some of Gomphroa species need to 
undergo molecular analysis first. The same can be said for the Cryptazeca/Hypnocarnica clade (Figs 1-3).

\section{CORRIGENDUM}

In our previous paper (MANGANELLI et al. 2019), the authorship of four taxa was incorrectly attributed to Bourguignat, 1858 (Hypnophila, Gomphroa emiliana, Gomphroa incerta) or to Bourguignat, 1864 (Gomphroa psathylorena). The correct date of publication of all is 1859 (see BANK et al. 2019). Moreover, in the captions of figs 75-76 and figs 77-78 (in MANGANELLI et al. 2019) showing Gomphroa cf. cylindracea, the authorship was incorrectly indicated as Bourguignat, 1858 instead of Calcara, 1840.

\section{REFERENCES}

ARMBruster G. F. J., BOEHME M., BERNHARD D., SCHLEGEL M. 2005. The $\mathrm{H} 3 / \mathrm{H} 4$ histone gene cluster of land snails (Gastropoda: Stylommatophora): TS/TV ratio, GC3 drive and signals in stylommatophoran phylogeny. Journal of Molluscan Studies 71: 339-348. https://doi. org/10.1093/mollus/eyi038

BANK R. A., Neubert E. 2017. Checklist of the land and freshwater Gastropoda of Europe. Last update: July 16th, 2017. Available on-line at http://www.marinespecies.org/aphia.php? $\mathrm{p}=$ sourcedetails\&id $=279050$ (accessed 20 March 2020)

BANK R. A., FAlKNer G., FAlKNer M., NeUbert E. 2019. The malacological publications of Jules-René Bourguignat: a bibliography. Basteria 83: 59-90.

BOETTGER C. R. 1949. Eine neue Landschnecke von der Insel Corsica. Archiv für Molluskenkunde 78: 167-168.

Boettger O. 1885. Zur Fauna von Elis und Achaia. Nachrichtsblatt der Deutschen Malakozoologischen Gesellschaft 17: 117-123.

BOUCHET P., Rocroi J.-P., HAUSDORF B., KAIM A., KANO Y., NÜTZEL A., PARKHAEV P., SCHRÖDL M., STRONG E. 2017. Revised classification, nomenclator and typification of gastropod and monoplacophoran families. Malacologia 61: 1-526. https://doi.org/10.4002/040.061.0201

BourguignAT J. R. 1859. Aménités malacologiques; $\mathbb{S}$ LXVIII. Notice monographique sur le genre Azeca. Revue et Magasin de Zoologie pure et appliquée (2) 10(12): 527-545; 11(1): 16-21.

CALCARA P. 1840. Monografie dei generi Clausilia e Bulimo, coll'aggiunta di alcune nuove specie di conchiglie siciliane esistenti nella collezione della Sig. Teresa Gargotta in Salinas. Giornale di Scienze, Lettere ed Arti per la Sicilia 76: 1-54.

CANTRAine F. 1835. Les diagnoses ou descriptions succintes de quelques espèces nouvelles de mollusques. Bulletins de l'Académie Royale des Sciences et BellesLettres de Bruxelles (1) 2 (11): 380-401.

Cianfanelli S., Bodon M., GiUsti F., MANGANELli G. 2018a. Gomeziella: a new genus for a living fossil (Gastropoda: Pulmonata: Azecidae). Basteria 82: 19-27.

\section{ACKNOWLEDGEMENTS}

HELEN AMPT (Siena, Italy) revised the English. SimONE CiANFANELli (Museo di Storia Naturale, Sezione Zoologica de "La Specola", Università di Firenze, Italy), BENJAMIN GómEZ (Universidad País Vasco; Vitoria-Gasteiz, Spain) and VeSNA ŠTAMOL (Croatian Natural History Museum; Zagreb, Croatia) loaned material from the collections of their museums or institutions. We also thank three anonymous reviewers for their valuable comments on the manuscript.

Cianfanelli S., BODON M., SOMOZA E., GómeZMOLINER B. J. 2018b. A new azecid from the Carnic Pre-Alps: Hypnocarnica micaelae gen. et sp. nov. (Gastropoda: Eupulmonata: Azecidae). Archiv für Molluskenkunde 147: 87-100. https://doi.org/10.1127/arch. moll/147/087-100

Colgan D. J., Mclauchlan A., Wilson G. D. F., Livingston S., EDGECOMBE G. D., MACARANAS J., CASSIS G., GRAY M. R. 1998. Histone H3 and U2 snRNA sequences and arthropod molecular evolution. Australian Journal of Zoology 46: 419-437. https://doi. org/10.1071/ZO98048

DEWAARD J. R. 2017. Canadian National Parks Data Release. Available on-line at https://www.ncbi.nlm.nih. gov/nuccore/MF545160 (accessed 25 April 2018).

DUPUY D. 1851. Histoire naturelle des mollusques terrestres et d'eau douce qui vivent en France. $4 \mathrm{e}$ fascicule: [3 pp.], 331-458. Masson, Paris.

FELSENSTEIN J. 1985. Confidence limits on phylogenies: an approach using the bootstrap. Evolution 39: 783-791. https://doi.org/10.1111/j.1558-5646.1985.tb00420.x

FLEMING J. 1828. A history of British animals, exhibiting the descriptive characters and systematic arrangement of the genera and species of quadrupeds, birds, reptiles, fishes, Mollusca, and Radiata of the United Kingdom; including the indigenous, extirpated, and extinct kinds, together with periodical and occasional visitants. Bell \& Bradfute, Edinburgh. https://doi.org/10.5962/bhl. title.12859

Folin A. G. L. DE, BÉRILlON F. 1877. Contribution à la faune malacologique de la région extrême S.-O. de la France. Bulletin de la Société de Borda à Dax 2: 199-210.

Folmer O., Black M., HoeH W., Lutz R. A., VRIJENHOEK R. C. 1994. DNA primers for amplification of mitochondrial cytochrome $\mathrm{c}$ oxidase subunit I from diverse metazoan invertebrates. Molecular Marine Biology and Biotechnology 3: 294-299.

GitTENBERGER E. 1983. On Iberian Cochlicopidae and the genus Cryptazeca (Gastropoda, Pulmonata). Zoologische Mededelingen 57: 301-320. 
GIUSTI F. 1970. Notulae Malacologicae. XI. Alcune nuove specie di Molluschi terrestri dell'Isola di Sardegna. Atti della Società Toscana di Scienze Naturali Residente in Pisa Memorie Serie B 77: 67-87.

GiUSTI F., MANGANELLI G. 1984. Relationships between geological land evolution and present distribution of terrestrial gastropods in the western Mediterranean area. In: SOlEM A., BRUGGEN A. C. VAN (eds). Worldwide snails. Biogeographical studies on non-marine Mollusca. Brill, Leiden, pp. 70-92.

Glez-Peña D., Gómez-Blanco D., Reboiro-Jato M., FDEZ-RIVEROLA F., POSADA D. 2010. ALTER: program-oriented format conversion of DNA and protein alignments. Nucleic Acids Research 38 (Web Server issue): W14-W18. https://doi.org/10.1093/nar/gkq321

HALl T. A. 1999. BioEdit: a user friendly biological sequence alignment editor and analysis program for Windows 95/98/NT. Nucleic Acids Symposium Series 41: 95-98.

Holyoak D. T., HolyOAK G. A. 2012. A review of species-limits in some Cryptazeca (Gastropoda: Azecidae). Iberus 30: 91-102.

JUKES T. H., CANTOR C. R. 1969. Evolution of protein molecules. In: MUNRO H. N. (ed.). Mammalian protein metabolism. Academic Press, New York, pp. 21-132. https://doi.org/10.1016/B978-1-4832-3211-9.50009-7

KimURA M. 1980. A simple method for estimating evolutionary rate of base substitutions through comparative studies of nucleotide sequences. Journal of Molecular Evolution 16: 111-120. https://doi.org/10.1007/ BF01731581

KumAR S., STECHER G., TAMURA K. 2016. MEGA7: Molecular Evolutionary Genetics Analysis version 7.0 for bigger datasets. Molecular Biology and Evolution 33: 1870-1874. https://doi.org/10.1093/molbev/msw054

Madeira M. J., Elejalde M. A., Chueca L. J., GómezMOLINER B. J. 2010. Phylogenetic position of the genus Cryptazeca and the family Azecidae within the system of the Stylommatophora. Malacologia 52: 163-168. https://doi.org/10.4002/040.052.0110

MANGANElli G., BARBATO D., PIEŃKOWSKA J. R., BENOCCI A., LESICKI A., GIUSTI F. 2019. Unravelling the tangle of the azecid land snails: a survey on the supraspecific systematics based on comparative morphology and molecular phylogeny (Gastropoda: Eupulmonata: Orthurethra). Folia Malacologica 27: 253-291. https:// doi.org/10.12657/folmal.027.031

MOUSSON A. 1873. Diagnosen neuer Mollusken aus WestMarocco von Dr. von Fritsch und Dr. Rein gesammelt. Malakozoologische Blätter 21: 149-157.

MÜlleR O. F. 1774. Vermium terrestrium et fluviatilium, seu animalium infusiorium, helminthicorum, et testaceorum, non marinorum, succincta historia. Vol. II. Heineck \& Faber, Havniae et Lipsiae. https://doi. org/10.5962/bhl.title. 12733

OzIMEC R. 2012. Ecology, biodiversity and vulnerability of Šipun Cave (Cavtat, Dubrovnik, Croatia). Natura Croatica 21 (suppl. 1): 86-90.
PAULUCCI M. 1882. Note malacologiche sulla fauna terrestre e fluviale dell'isola di Sardegna. Bullettino della Società Malacologica Italiana 8: 139-381.

PAUluCCI M. 1886. Fauna Italiana. Comunicazioni malacologiche. Articolo nono. Conchiglie terrestri e d'acqua dolce del Monte Argentaro e delle isole circostanti. Bullettino della Società Malacologica Italiana 12: 5-64.

PieŃKOWSKA J. R., MANGANELli G., GiUsti F., HALlGASS A., LESICKI A. 2018. Exploring Monacha cantiana (Montagu, 1803) phylogeography: cryptic lineages and new insights into the origin of the English populations (Eupulmonata, Stylommatophora, Hygromiidae). ZooKeys 765: 1-41. https://doi.org/10.3897/zookeys.765.24386

PiEŃKOWSKA J. R., MANGANELLI G., GIUSTI F., BARBATO D., HALLGASS A., LESICKI A. 2019. Exploration of phylogeography of Monacha cantiana s.l. continues: the populations of the Apuan Alps (NW Tuscany, Italy) (Eupulmonata, Stylommatophora, Hygromiidae). ZooKeys 814: 115149. https://doi.org/10.3897/zookeys.814.31583

PORRo C. 1838. Malacologia terrestre e fluviale della Provincia Comasca. Guglielmini e Redaelli, Milano. https://doi.org/10.5962/bhl.title.12948

RONQUIST F., HUELSENBECK J. P. 2003. MRBAYES 3: Bayesian phylogenetic inference under mixed models. Bioinformatics 19: 1572-1574. https://doi. org/10.1093/bioinformatics/btg180

ROTH J. R. 1855. Spicilegium molluscorum orientalium annis 1852 et 1853 collectorum. Malakozoologische Blätter 2: 17-58.

ŠTAMOl V., MANGANELli G., BARBATO D., GiUsti F. 2018. Hypnophila zirjensis n.sp., a new azecid land snail from the Croatian island of Žirje (Gastropoda: Pulmonata: Orthurethra). Journal of Conchology 43: 1-14.

TAMURA K. 1992. Estimation of the number of nucleotide substitutions when there are strong transition-transversion and $\mathrm{G}+\mathrm{C}$-content biases. Molecular Biology and Evolution 9: 678-687.

Thompson J. D., Higgins D. G., Gibson T. J. 1994. CLUSTAL W: improving the sensitivity of progressive multiple sequence alignment through sequence weighting, position-specific gap penalties and weight matrix choice. Nucleic Acids Research 22: 4673-4680. https://doi.org/10.1093/nar/22.22.4673

WADE C. M., MORDAN P. B. 2000. Evolution within the gastropod molluscs; using the ribosomal RNA gene-cluster as an indicator of phylogenetic relationships. Journal of Molluscan Studies 66: 565-570. https://doi. org/10.1093/mollus/66.4.565

WADE C. M., MORDAN P. B., ClARKE B. 2001. A phylogeny of the land snails (Gastropoda: Pulmonata). Proceedings of the Royal Society B: Biological Sciences 268: 413422. https://doi.org/10.1098/rspb.2000.1372

WATSON H. 1920. The affinities of Pyramidula, Patulastra, Acanthinula, and Vallonia. Proceedings of the Malacological Society of London 14: 3-30.

WELTER-SCHULTES F. 2012. European non-marine molluscs, a guide for species identification. Bestimmungsbuch für europäische Land- und Süsswassermollusken. Planet Poster Editions, Göttingen. 
Westerlund C. A. 1902. Methodus dispositionis conchyliorum extramarinorum in Regione palaearctica viventium, familias, genera, subgenera, et stirpes sistens. Rad Jugoslavenske Akademije Znanosti i Umjetnosti, Matematičko-Prirodoslovni Razred 151:

Received: July 3rd, 2020

Revised: September 23rd, 2020

Accepted: September 25th, 2020 Published on-line: October 12th, 2020 82-139. 